371.3::821.163.41-2

https://doi.org/10.18485/kij.2020.67.2.9

НАТАША Б. СТАНКОВИЋ ШОШО*

Универзитет у Београду

Филолошки факултет
Оригинални научни рад

Примљен: 27.11.2020.

Прихваћен: 14.12.2020.

\title{
ЛИТЕРАРНО И ТЕАТРОЛОШКО ЧИТАЬЕ КОМЕДИЈЕ У ОСНОВНОЈ ШКОЛИ
}

\begin{abstract}
У раду се сагледава заступљеност комедија у реформисаним наставним програмима предмета Српски језик и књижевност у основној школи, са циљем да се пронађу ваљана методичка гледишта у њеном наставном проучавању, али и укаже на методичке изазове које овај жанр у настави ствара. У раду се анализира како литерарно и театролошко читање комедије и наставни контекст у коме се читање обавља утичу на остваривање естетских, образовних, васпитних и функционалних циљева и доприносе усвојености исхода.
\end{abstract}

Кључне речи: комедија, настава, наставни програм, српски језик и књижевност, литерарно и театролошко проучавање, стваралачке активности.

У реформисаним наставним програмима Српског језика и књижевности за основну школу, који су одобрени у периоду од 2017. до 2020. године, заступљена су репрезентативна комедиографска остварења класика српске књижевности (Јована Стерије Поповића, Косте Трифковића, Бранислава Нушића) и значајног комедиографа светске књижевности (Жана Батиста Поклена Молијера). Комедије које се читају и тумаче у основној школи чине саставни део обавезне школске или домаће лектире и припадају канонском корпусу националне и светске књижевности. Поједина комедиографска остварења проучавају се у целости као обавезна домаћа лектира, чиме се развијају и негују континуиране навике читања код ученика.

Заступљеност комедија у реформисаним наставним програмима за основну школу представићемо следећим табеларним приказом:

"natasoso06@gmail.com 
Табела 1. Заступљеност комедија у наставним програмима за основну школу

\begin{tabular}{|c|c|c|c|}
\hline V разред & VI разред & VII разред & VIII разред \\
\hline / & $\begin{array}{l}\text { Коста Трифко- } \\
\text { вић: Избирачица } \\
\text { (одломак) }\end{array}$ & $\begin{array}{l}\text { Бранислав } \\
\text { Нушић: Власm } \\
\text { (одломак) }\end{array}$ & $\begin{array}{l}\text { Жан Батист По- } \\
\text { клен Молијер: } \\
\text { Грађанин племић } \\
\text { (одломак) }\end{array}$ \\
\hline $\begin{array}{l}\text { Јован Стерија } \\
\text { Поповић: } \\
\text { Лажа и пара- } \\
\text { лажа (одломак } \\
\text { о Месечевој } \\
\text { краљици) - } \\
\text { допунски избор } \\
\text { домаће лектире }\end{array}$ & / & $\begin{array}{l}\text { Јован Стерија } \\
\text { Поповић: Покон- } \\
\text { дирена тиква- } \\
\text { обавезна домаћа } \\
\text { лектира }\end{array}$ & $\begin{array}{l}\text { Бранислав Ну- } \\
\text { шић: Сумњиво } \\
\text { лице - обавезна } \\
\text { домаћа лектира }\end{array}$ \\
\hline
\end{tabular}

Програм наставе и учења за пети разред основног образовања и васпи$m a њ a$ прописује да ученици у оквиру допунског избора домаће лектире могу да прочитају одломак о Месечевој краљици из комедије Лажа и паралажа Јована Стерије Поповића. Наставна интерпретација наведеног одломка није условљена познавањем књижевнотеоријских појмова о комедији, њеним особеностима и подврстама. Наведени одломак омогућава ученицима да током доживљајног читања развијају имагинацијски богате асоцијације о прочитаном тексту и да га интерпретирају на основу властитих утисака и личних доживљаја. Ученици ће бити у прилици да образлажу властите естетске утиске и интерпретативна запажања током тумачења наведеног одломка (илуструју особине ликова примерима из текста, вреднују њихове поступке и аргументовано износе своје ставове). Наведени одломак може да буде и погодан литерарни предложак при обради наставних јединица из граматике и правописа, чиме се остварује унутарпредметна корелација наставних садржаја.

Комедије Избирачица Косте Трифковића, Покондирена тиква Јована Стерије Поповића, Власт и Сумњиво лице Бранислава Нушића обрађују се у целости током шестог, седмог и осмог разреда основне школе, док се Молијеров Грађанин племић обрађује у одломцима у осмом разреду. Избор комедиографских остварења која се проучавају у основној школи примерен је узрасту ученика и омогућава да се код ученика „развијају читалачке компетенције које подразумевају не само истраживачко посматрање и стицање знања о књижевности већ подстичу и развијају емоционално и фантазијско уживљавање, имагинацију, 
естетско доживљавање, богате асоцијативне моћи, уметнички сензибилитет, критичко мишљење и изграђују морално просуђивање". ${ }^{1}$

У методици наставе књижевности указано је на неопходност да се тумачење драмског дела остварује здруженим литерарним и театролошким приступом. ${ }^{2}$ „Али треба запазити да свако ваљано проучавање драме не запоставља ни њене књижевне, ни њене сценске посебности. Ти различити аспекти драме нису раздвојени, нити се један одлаже због другог или на рачун њега, а у складу са узрастом ученика, из вида се не губе ни односи драмског дела према другим делима у културној традицији: музици, ликовној уметности, сценском покрету” (Бајић 2013).

При наставној обради комедија у основној школи афирмише се доживљајно, истраживачко и изражајно-интерпретативно читање репрезентативних комедиографских остварења. Ученици се оспособљавају да искажу свој доживљај комедиографског дела, анализирају елементе од којих је дело сачињено и разумеју њихову улогу у делу. Аналитичко-синтетичким поступцима проучавају се доминантне уметничке вредности, посебно литерарни проблеми, особеност ликова, начини испољавања њихових унутрашњих конфликата и сукоби са другим актерима драме и средином, динамичност радње, хумористички поступци и њихова улога у разоткривању моралних слабости ликова, уметничка средства хумористичког и сатиричног разобличавања социјалних и неморалних појава приказаних у комедији, облици вербалне и ситуационе комике и доминантни облици казивања (дијалог, монолог). Помоћу естетских и идејних вредности обрађених комедиографских остварења код ученика се развија смисао за хумор, али и за морално и племенито у животу. Ученици ће увиђати да су полтронство, властољубље и ускогрудост узроци сукоба међу људима, који доводе до моралне посрнулости друштва и грађана. Критички ће сагледати погубност деловања неодговорне, корумпиране и самовољне власти на вредносни систем друштва у целини. Аргументовано ће указати на погубност лицемерја, користољубља, неодговорности, осионости, примитивизама и површности представника власти и бирократије. Тумачиће узроке и последице нездраве амбициозности ликова, која почива на несагласју нереалних жеља и потреба и стварних могућности. Откриваће важност објективног сагледавања властитих способности. Литерарно и театролошко проучавање наведених комедија утиче на формирање естетског укуса код ученика, изграђује њихове моралне вредности и развија њихова критичка гледишта према друштвеним и моралним изопачењима приказаним у делима.

Реформисани програми за основну школу унели су новине прописујући књижевнотеоријске појмове који се током наставног проучавања комедија усвајају и исхода (описа интегрисаних знања, вештина, ставова и вредности) које ученици током њихове наставне интерпретације стичу, развијају, проширују и

\footnotetext{
${ }^{1}$ „Програм наставе и учења за пети разред основног образовања и васпитања” (Службени гласник РС, бр. 15/18).

${ }^{2} \mathrm{O}$ неопходности литерарног и театролошког приступа драмском тексту писала је проф. др Љиљана Бајић у студији Читање драме (в. Бајић 2013).
} 
примењују. У основној школи ученици стичу основна знања о особеностима комедије и њеним врстама (комедија ситуације, комедија карактера и комедија нарави), као и основна знања из теорије и историје драмске и позоришне уметности.

Читајући и тумачећи комедију Избирачица Косте Трифковића, ученици увиђају да се у комедији, на различите начине, приказују комични јунаци, који својим говором, поступцима, неприлагођеношћу ситуацији и односом према другим ликовима изазивају смех и откривају да се драмска радња заснива на брижљиво припремљеним комичним ситуацијама и неочекиваном обрту (ситуација се увек окреће против лица који је ствара). Током наставне интерпретације наведене комедије ученици ће научити да комедију ситуације карактерише понављање истих призора с различитим учесницима, дублирање (удвајање ликова), замена улога, обрт ситуације и комика речи (извртање речи и реченица, игра речи, смешна имена јунака, иронија, досетке). Пописани исходи садржани у програму за шести разред основношколског образовања и васпитања предвиђају да ученици самостално користе књижевне термине и појмове обрађиване у претходним разредима и да их повезују са новим делима која читају. За интерпретацију и адекватно поимање овог комплексног комедиографског жанра неопходно је да ученици примене књижевнотеоријска знања о драми која су усвојили у петом и шестом разреду, као што су: драмска радња, драмска лица, драмски сукоб, чин, слика, призор, монолог, дијалог, дидаскалије.

Литерарним проучавањем комедије Покондирена тиква Јована Стерије Поповића ученици у седмом разреду проширују знања о комедији и увиђају које су особености комедије карактера. Полазећи од сазнања да се у комедији на реалистичан начин приказују живот и мане главног јунака и његови поступци (помодарство, малограђанштина, примитивизам) на духовит начин, они откривају да смисао комичног почива на нескладу између жеља протагонисте и немогућности да те жеље оствари. Та сазнања о комедији карактера ученици ће применити у осмом разреду током читања и тумачења одломака из Молијерове комедије Грађанин племић, у којој су преувеличане мане главног лика, Журдена, а комични ефекти се постижу његовим суочавањем са другим ликовима, који стварају заплет користећи се тим његовим особинама.

Комедије Власт и Сумњиво лище повезује сродна проблематика. Ликови у тим комедијама представљени су описом физичког изгледа у датом простору (у дидаскалијама), приказивањем њихових поступања у различитим ситуацијама, изношењем исказа јунака о себи на сцени (дијалогом и монологом) и сведочењем других драмских лица о њима. Жеља за богаћењем и поседовањем власти постају главни мотивацијски покретачи актера, како главних, тако и споредних. У наставној интерпретацији Нушићевих комедија посебна пажња посветиће се етичкој (моралној) и говорној (језичкој) карактеризацији драмских лица, као и њиховој улози у комичком заплету. Уз помоћ вербалне и ситуационе комике ученици ће откривати изопаченост света који се приказује и спознати да хумор постаје непоткупљиво лице комада Власт и Сумъиво лице које омогућује да се 
разобличе и осуде неморални поступци актера комада и уочавати повезаност моралних изопачења власти и појединца. Тумачећи Нушићеву комедију Сумњиво лище, ученици ће разоткривати неодговорност и бахатост бирократског менталитета и са моралног становишта просуђивати поступке представника власти. Ваљана наставна интерпретација поменуте комедије код ученика ће развијати критичку свест о штетности таквог деловања и подстицати потребу да га осуде и одбаце у свим друштвима и временима. Током наставне интерпретације комедије Сумьиво лице Бранислава Нушића, ученици ће усвајати основна знања о комедији нарави, као подврсти комедије у којој се исмевају навике, обичаји и схватања одређене генерације, друштвене групе или епохе.

„Књижевнотеоријске појмове ученици ће упознавати уз обраду одговарајућих текстова и помоћу осврта на претходно читалачко искуство" (Службени гласник PC, бр. 15/18: 83). Дакле, интерпретација комедиографског текста, уважавајући и све друге образовне, васпитне и практичне циљеве, омогућава да се у настави усвоје доминантни књижевнотеоријски термини који доприносе бољем сагледавању датог дела са литерарног аспекта. Књижевнотеоријска знања о драми која ће ученици усвојити тумачећи комедије Избирачица, Власт, Покондирена тиква, Грађанин племић и Сумњиво лице, као што су: сценски елементи (посебно сценски простор и говор), кинезички и проксемички знаци (мимика, гест и држање) и визуелна и аудитивна средства у драми (маска, костим, светлосни и звучни елементи) и њихова функција на сцени, режија, глума, мизансцен, сценографија, расвета, костими, етапе у развоју драмске радње, дидаскалије, позоришна представа, омогући ће им да проуче Молијерове, Стеријине и Нушићеве комедије и са театролошког аспекта.

Образлажући неопходност методичке концепције о повезаности и упоредности проучавања драмске и сценске уметности у настави, Љиљана Бајић истиче да се „литерарни и театролошки приступ може [...] остварити помоћу следећих облика и садржаја рада:

1. истраживачко и сценско читање комедија;

2. навикавање ученика да током читања и проучавања комедије откривају и заузимају различита гледишта на уметнички свет књижевног дела, као и да се повремено нађу у улози редитеља, глумца, костимографа, сценографа;

3. поредбено тумачење комедије и његове сценске реализације;

4. посматрање позоришне представе и њено критичко просуђивање;

5. театролошки увид у драмско дело, односно у сценске елементе (посебно сценски простор и говор), кинезичке и проксемичке знакове (мимику, гест и држање драмских лица) и визуелна и аудитивна средства у драми (маску, костим, светлосне и звучне елементе) и у њихову функцију на сцени;

6. развијање унутрашње чулности и сценске имагинације путем задатака који подстичу на увиђање књижевних и сценских чинилаца драмског 
дела (од радње и ликова, преко изгледа и детаља позорнице и говора ликова на сцени, до глумачке интерпретације и режијске концепције);

7. афирмисање драмског и сценског стваралаштва ученика (од читања драмског текста по улогама, преко драматизације текста, и стварања позоришних мапа, до писања оригиналних књижевних и сценских редакција драмског текста и позоришних и књижевних приказа и критика" (2013).

Избор комедија које се читају и тумаче у основној школи омогућава примену компаративног приступа проучавања драмске и сценске уметности, уз одабир различитих нивоа обраде: интерпретације, приказа или осврта. Да би наставна интерпретација комедија била заснована на литерарном и театролошком приступу, неопходно је да се комедије читају у целости и проучавају током два школска часа, а да се на часовима језичке културе сценски реализују одабрани одломци из комедија, као и да се предвиде посебни часови на којима би се гледале позоришне представе и разговарало са ученицима о театролошким аспектима обрађених комедиографских остварења.

У настави Српског језика и књижевности важно је подстаћи ученике да гледају позоришне представе које су у вези са комедијама који се проучавају у школи. За многе ученике организована школска посета позоришту уједно је и први сусрет са сценском уметношћу. Позоришна и филмска уметност знатно доприносе развоју свестране личности ученика, утичу на интелектуални, емоционални и културни развој ученика, развијају њихову критичку свест и подстичу их на стваралаштво. Неопходно је ученике упознати са позоришним остварењима, филмским и ТВ драмама. На тај начин се ученици припремају да тумаче комедије Избирачица, Покондирена тиква, Власт, Грађанин племић и Сумњиво лице и са театролошког становишта (посебно изражајне сценске знакове, режијску поставку и глумачка достигнућа у одговарајућој позоришној представи). Обрадом комедија неопходно је неговати позоришну културу ученика (познавање стваралачких достигнућа значајних драматурга, редитеља, глумаца, сценографа, костимографа, познавање позоришног репертоара) и подстицати и развијати критички однос ученика у проблемском и поредбеном приступу делу. Део наставног програма могуће је реализовати у културној институцији (позоришту, биоскопу, музеју) и на тај начин омогућити ученицима непосредан сусрет са уметничким делима. Осим тога, било би добро мотивисати ученике да погледају филмска и позоришна остварења која су доступна на интернету.

Дигиталне технологије се почетком 21. века уводе у основношколску и средњошколску наставу што је у складу са Стратегијом развоја образовања y Републици Србији до 2020. године и значајним улагањима Министарства просвете, науке и технолошког развоја у опремање дигиталних учионица и обуку наставника у примени информационо-комуникационих технологија у образовно-васпитном раду. Један од приоритетних циљева примене дигиталних технологија у савременој настави јесте да њена иновативност допринесе постизању 
вишег нивоа остварености стандарда образовних постигнућа ученика. Одобрени е-уџбеници (интерактивне читанке и граматике за основну школу), као савремена дидактичка средства у настави српског језика и књижевности садрже звучне записе, инсерте из позоришних представа и наставне филмове о животу и раду знаменитих комедиографа и мотивишу ученике за читање књижевних дела, подстичу и унапређују њихово учење, активирају истраживачку радозналост ученика, подржавају диференцирање и индивидуализацију наставе и учења, олакшавају ученицима приступ релевантним научним знањима, побуђују сарадничку радну атмосферу на часу и доприносе остварењу програмом дефинисаних образовних исхода. Примена информационо-комуникационих технологија и дигиталних медија у настави има значајну улогу и унапређује процес учења у основним школама.

Наставник може подстаћи ученике да чују одговарајући аудио-запис у којем је снимљено изражајно (интерпретативно) читање професионалних глумаца како би тумачили и вредновали њихову говорну интерпретацију на следећи начин:

- Нушићев комад Сумњиво лище, као драмски текст, намењен је за извођење у позоришту. Послушајте у звучној читанци (издавачка кућа „Нови Логос”з) почетак комедије у интерпретацији глумаца Наде Блам и Миленка Павлова. - Док слушате разговор капетана Јеротија Пантића и његове супруге Анђе, замишљајте сценски простор и поступке драмских лица, актера овог призора. Обратите пажњу на атмосферу у којој се одвија њихов разговор. Уочавајте драматуршке посебности дијалога (темпо, динамику смењивања дијалошких реплика). - Спремите се да наведете шта сте на основу дијалога сазнали о моралним и карактерним особинама Јеротија и Анђе, али и о драмским лицима која су тема њиховог разговора. - Запажајте посебности у говору Јеротија и његове супруге. Објасните на који начин посебности у језику доприносе карактеризацији драмских лица.

Таквим поступањем наставник актуелизује питање рецепције код ученика. Пошто су чули интерпретацију професионалних глумаца, наставник може подстаћи ученике да прочитају одломак из комедије који је на њих оставио посебан утисак и да приликом читања запажају, замишљају и вреднују доминантне естетске чиниоце у тексту на следећи начин:

- Наведите делове текста и реплике који су оставили најснажније утиске на вас. Шта вас је посебно насмејало? Објасните зашто. - Делови драмског текста су, осим дијалога и монолога, и дидаскалије. Запажајте делове драмског текста у којима се налазе упутства о изгледу сцене, о кретању и начину говора ликова, о месту радње. Образложите каква је функција таквих напомена. Коме су оне упућене? С којом намером?

\footnotetext{
${ }^{3}$ Звучна читанка за 8. разред, Издавачка кућа „Нови Логос”, Београд, 2010, нумера бр. 7.
} 
Проучите на који начин дидаскалије (ремарке) помажу читаоцу да се уживи у текст, да замисли изглед ликова и простор у којем се радња одвија.

У настави је добро подстицати ученике у изражајном и интерпретативном читању драмског текста по улогама и заинтересовати их да припреме извођење ове комедије на сцени. Краћи одломци из обрађених комедија у дијалошком или монолошком виду погодни су за учење напамет. Наставник ће скренути пажњу ученицима да приликом припремања за изражајно и интерпретативно читање уочавају емоционалну динамику текста, вербални хумор и драматичност изреченог.

- Док читате одабрани одломак из комедије, нагласите (јаче изговорите и тон нагло подигните) речи које су носиоци информације. Обратите пажњу на интонацију гласа приликом изговарања узвика. Значење узвика у говору истакните подизањем или спуштањем тона. - Поред правилног дисања, за темпо казивања важне су и паузе, које се праве да би се означио крај реченице и да би се осмислило оно што се жели рећи. Водите рачуна да правите паузе како бисте удахнули ваздух и правилно дисали док читате. - Паузе у писању обележавају се знаковима интерпункције: запетом, тачком, тачком и запетом, са три тачке. Интерпункцијски знаци нам помажу да знамо када правимо предах у говору. Најдуже паузе направите после три тачке. Нешто краће паузе после тачке, а мање предахе после запете. Паузу можете правити и када очекујете реакцију саговорника или неки важан одговор.

Током вежбања изражајног и интерпретативног казивања текста по улогама, наставник сугерише ученицима да текст казују из перспективе појединих драмских лица, да током казивања посматрају саговорника „очи у очи” и да успостављају емоционални контакт у складу са упутствима из дидаскалија. Наставник таквим поступањем припрема ученике да у поузданом и сугестивном казивању одломка из комедије посвете пажњу изражајним могућностима говорног језика и остваре непосредност у сценском покрету. Настава ће бити продуктивнија уколико се изражајно казивање ученика сними аудио или визуелном техником (диктафоном, мобилним телефоном или камером). Слушајући или гледајући снимак, ученици ће уочавати посебности и недостатке дикције, изражајног говора и мимике и континуираним радом поступно усавршавати сценски говор и покрет.

Усавршавање изражајног читања и развијање личног тона при читању и казивању напамет научених драмских целина унапредиће говорну културу ученика, обогатити њихов лексички фонд, усавршити језички и стилски израз. Репрезентативан одломак из комедије прочитан на одговарајући начин доживљајно, изражајно и интерпретативно биће најнепосреднији подстицај ученицима да се уживе у хумористични свет драмског дела и развију читалачке навике и уметнички укус. 
Значајни су и облици рада подстакнути текстом којима се додатно подстичу разноврсни истраживачки и стваралачки приступи у настави. Познато је да укључивање стваралачких активности у наставни процес унапређује креативне, истраживачке и продуктивне способности читања и интерпретације књижевних дела, као и говорне и литерарне вештине ученика. Наставне активности подстакнуте драмским текстом развијају стваралаштво ученика (од читања драмског текста по улогама, преко драматизације текста, до писања позоришних и књижевних приказа и критика). Ученици се подстичу да напишу литерарни састав на задату тему, да осмисле краћи реферат, приказ или есеј у којима ће тумачити ликове, тематски и идејни слој обрађених комедија и одгледаних позоришних представа или филмских остварења. Самостално излагање на основу резултата тумачења комедија остварује се писањем састава одговарајуће тематике: Избирач пронађе отирач, Свако време има своје Феме, Дај некоме власт да видиш какав је човек, Положај младих у савременом друштву, Човек и власт, Власт и стваралаштво.

Комедије Избирачища, Покондирена тиква, Власт, Грађанин племић и Сумъиво лице погодне су за извођење у оквиру слободних школских активности (посебно у раду драмске секције). Ученици који показују посебна интересовања за драмско стваралаштво, филмску и сценску уметност могу на часовима додатног рада да драматизују сцену из предговора Нушићеве комедије Сумњиво лице која је на њих оставила посебан утисак или да адаптирају сцену Нушићевог разговора са Милорадом Шапчанином, са Николом Петровићем или дијалог Нушића - писца са Нушићем - управником. Ученици се подстичу и да осмисле сцену хапшења „сумњивог лица” у хотелу Европа и напишу текст у драмском облику или да доврше комедију Власт на оригиналан начин.

Здружено литерарно и театролошко читање програмом прописаних репрезентативних комедиографских остварења и њихово тумачење, облици рада подстакнути текстом и наставни контекст у коме се обављају утичу на остваривање естетских, образовних, васпитних и функционалних циљева и доприносе усвојености исхода. Литерарни и театролошки приступ у настави омогућава да ученици остварују активан однос према комедијама, доживљавају их асоцијативно, фантазијски и личним пројектовањем, уживају у читању и спознају њихове врхунске естетске вредности.

\section{ИЗВОРИ}

„Правилник о наставном програму за шести разред основног образовања и васпитања", Службени гласник Републике Србије - Просветни гласник, год. LVII - бр. 5/2008, Београд, 2008.

„Правилник о наставном програму за седми разред основног образовања и васпитања", Службени гласник Републике Србије - Просветни гласник, бр. 6/2009, Београд, 2009. 
„Правилник о наставном програму за осми разред основног образовања и васпитања", Службени гласник Републике Србије - Просветни гласник, бр. 2/2010, Београд, 2010.

„Правилник о програму наставе и учења за пети разред основног образовања и васпитања”, Службени гласник РС - Просветни гласник, бр. 9/17, Београд, 2017.

„Правилник о програму наставе и учења за шести разред основног образовања и васпитања", Службени гласник РC - Просветни гласник, бр. 5/18, Београд, 2018.

„Правилник о програму наставе и учења за седми разред основног образовања и васпитања”, Службени гласник РС - Просветни гласник, бр. 5/19, Београд, 2019.

„Правилник о програму наставе и учења за осми разред основног образовања и васпитања", Службени гласник РС - Просветни гласник, бр. 5/20, Београд, 2020.

\section{ЛИТЕРАТУРА}

Бајић 2013: Љ. Бајић, „Читање драме”, Кюижевност и језик, LX, 3-4, Београд, 351-362.

Живковић 2001: Д. Живковић, Речник књижевних термина, Бања Лука: Романов.

Јакшић Провчи 2001: Б. Јакшић Провчи, „Проучавање дидаскалија у наставном процесу", Кюижевност и језик XLVIII, 3-4, Београд, 77-82.

Лешић 2008: 3. Лешић, Теорија књижевности, Београд: Службени гласник.

Lešić 1981: J. Lešić, Nušićev smijeh, Beograd: Nolit.

Lešić 1982: J. Lešić, Sumnjivo lice Branislava Nušića, Beograd: Zavod za udžbenike i nastavna sredstva.

Мисаиловић 1983: М. Мисаиловић, Комедиографија Бранислава Нушића, Београд: Универзитет уметности у Београду.

Солар 1982: М. Солар, Теорија књижевности, Загреб: Школска књига.

Станковић Шошо 2010: Н. Станковић Шошо, Мали речник књижевних термина за основну школу, Београд: Нови Логос.

Станковић Шошо 2019: Н. Станковић Шошо, Книжевно дело Бранислава Нушића у настави, Београд: Друштво за српски језик и књижевност Србије. 
Nataša B. Stanković Šošo

\title{
LITERARY AND THEATRICAL READING OF COMEDY IN PRIMARY SCHOOL
}

\begin{abstract}
Summary
The paper analyzes the representation of comedies in the reformed curriculum for primary school, with the aim of finding valid methodological points of view in its teaching study, but also points out the methodological challenges which this genre provides. The paper examines how the teaching context in which literary and theatrical reading is performed influences the achievement of teaching goals and outcomes of the subject Serbian language and literature.

Keywords: comedy, teaching, primary school curriculum, literary and theatrical reading of comedy, creative activities in teaching.
\end{abstract}

